\title{
Rozhovor s Jevgenijom Iršaiom
}

\author{
Peter Javorka
}

\begin{abstract}
"Nepredstieram, že som objektívny, dokonca si myslím, že objektivita je druh slepoty, ked'sa pozadie a popredie navzájom úplne neliši."
\end{abstract}

Joseph Brodsky z listu pre New York Times

Skladatel' a profesor kompozície Jevgenij Iršai v januári 2021 oslávil sedemdesiatku. Patrí medzi hudobných skladatel'ov, pedagógov, klaviristov, ktorých tvorba je mimoriadne rozsiahla na to, aby na ňu stačilo niekolko stránok rozhovoru, predsa však možno odkryt' významné inšpirácie pri rozhovore o jeho mladosti strávenej v Sankt Peterburgu, vtedajšom Leningrade, a o bezprostrednom kontakte $s$ jednou z najvýznamnejších svetových kultúr. Jevgenij Iršai v auguste 1991 emigroval na Slovensko, kde neskôr - okrem iného - zastával pozíciu vedúceho katedry skladby a dirigovania na Vysokej škole múzických umení v Bratislave a patrí medzi iniciátorov viacerých pozoruhodných umeleckých projektov.

Jeho hudba vzbudila záujem a priniesla do slovenského kultúrneho kontextu nový typ expresie. Často sa vyznačovala nenáhlivou, pomalou gradáciou vzrastajúcou na dlhej ploche, radikálnymi kontrastmi, temperamentom, ale tiež priam divadelným zmyslom pre dramaturgiu hudobnej výpovede. Nie je však len oceňovaným autorom hudby orchestrálnej, komornej či vokálnej, ale v minulosti aj filmovej. Jevgenij Iršai je taktiež autorom niekolkých desiatok esejí a venuje sa aj výtvarnej tvorbe. Ako pedagóg sa podielal na vzdelávaní mladej slovenskej skladatel'skej generácie.

Peter Javorka: Pán profesor, ste odchovancom jednej z najsilnejších svetových umeleckých kultúr. Študovali ste hru na klavíri a skladbu na Konzervatóriu Nikolaja Andrejeviča Rimského-Korsakova v Sankt Peterburgu, vtedajšom Leningrade, kde ste sa aj narodili a prežili niekolkko desatročí. Hoci viem, že ide o vel'mi širokú otázku, predsa sa pýtam, na čo by ste si z tohto obdobia spomenuli?

Jevgenij Iršai: Tých spomienok mám vel'mi vel'a. Možno by som si spomenul na kamarátov z detstva, na Divadelné námestie, kde sme bývali. Náš byt stál z jednej strany 
oproti Konzervatóriu a z druhej oproti Kirovovmu divadlu, opere a baletu, ktoré teraz zase má svoj pôvodný názov Mariinské divadlo... Alebo by som si spomenul na svoju prvú lásku, s ktorou sme raz v noci zbierali tulipány a ktorá vôlou osudu žije v USA. Predpokladám však, že vás skôr zaujímajú spomienky z profesionálneho hudobného prostredia.

Študovat' skladbu a hru na klavíri na Leningradskom konzervatóriu som začal v roku 1969. V 60. a 70. rokoch bola leningradská kompozičná škola vel’mi silná. Dá sa hovorit’ o určitom rozkvete, vyvrcholení. Práve počas týchto dvoch desatiročí mala leningradská škola ohromné množstvo skvelých a významných skladatel'ov. Patril medzi nich napríklad Boris Tiščenko, Sergej Slonimskij, Vladislav Uspenskij, Valerij Gavrilin, Lucian Prigožin, Andrej Petrov, Jurij Falik, Gennadij Banščikov, Alexander Knajfel', Galina Ustvolskaja, Georgij Firtič a mnoho iných.

Na Konzervatóriu - podotýkam, že v Rusku je to názov pre vysokú umeleckú školu - som študoval skladbu najprv pod vedením Alexandra Černova-Pena a následne, po jeho predčasnom úmrtí na rakovinu, som pokračoval pod vedením Vladislava Uspenského. Mal som štłastie, pretože obaja boli mimoriadne nadaní umelci a silné osobnosti. Alexander Černov-Pen na vysokej škole najprv vyštudoval odbor chémia a až potom zasvätil svoj život hudbe. Vynikajúco poznal ruskú a svetovú literatúru a poéziu. Študentov učil dôsledne pracovat’ so slovom, vyvíjal u nich cit a pochopenie pre dôležitost' dramaturgie v hudbe. Vladislav Uspenskij ma zasa viedol k presnému a zároveň aj vol'nému cíteniu hudobného času a k práci s detailmi. Je však samozrejmé, že tých vplyvov bolo vel'a. Takmer od každého som sa niečo naučil, aj ked' často podvedome. Pamätám si, že v prvom ročníku Konzervatória som pod vplyvom hudby Rodiona Ščedrina skomponoval niekol'ko krátkych trojminútových skladieb pre kvarteto drevených dychových nástrojov, ktoré zaradili na koncert v rámci festivalu Leningradská jar. Nečakane som zaznamenal výrazný úspech a pozvali ma aj do televíznej relácie. Môj vtedajší profesor Alexander Černov ma varoval, aby som nezačal byt’ príliš povýšený. Dotklo sa ma to a do televízie som nešiel. Nikdy som netúžil po sláve.

Mojím „kumirom“ (vzorom) ešte na strednej škole bol nesporne Boris Tiščenko. Hovorili o ňom, že je jedným z najoblúbenejších a najperspektívnejších žiakov Šostakoviča a jeho sláva či prestíž bola v 60. rokoch v Rusku vel'mi vel'ká. Práve jeho spôsob využitia kontrastov, jeho temperamentná, miestami až divoká, nekompromisná hudba mi bola vtedy vel'mi blízka. Do určitej miery mi ostala blízka dodnes.

Skladatelia, ktorých som menoval, sú na Slovensku takmer neznámi. Staršia generácia skladatelov ako Ilja Zeljenka, Ivan Hrušovský, Jozef Malovec, Juraj Beneš, Vladimír Bokes, Roman Berger, poznali niektorých aj osobne, pretože sem-tam sa stretávali s nimi na medzinárodných festivaloch či už v Leningrade alebo aj v Prahe, vo Varšave atd'.

Dnes mladá generácia pozná len tých, ktorí sú známi vo svete, ako Schnittke, Pärt, Gubajdulina, Kančeli alebo mladých skladatel’ov z Ruska, ktorí majú dobré kontakty v Európe a ich hudbu občas hrajú v Nemecku, Anglicku či inde. Niektorí z nich sa aj presídlili do Nemecka alebo Anglicka.

\section{P. J.: Spomenuli ste Alexandra Černova, Vladislava Uspenského, Rodiona Ščedrina, Borisa Tiščenka. Boli ešte nejakí iní skladatelia, ktorí výrazne vplývali na váš skla- datel'ský vývin?}




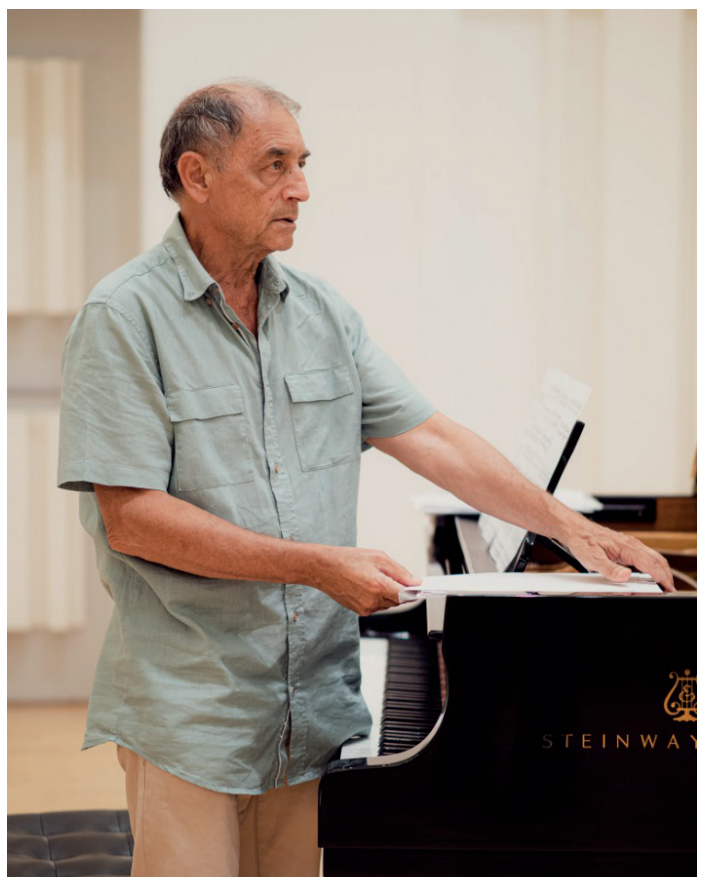

Obr. 1: Jevgenij Iršai. Foto z nahrávania CD albumu A Glass of Glass, 2020. (Foto: Karol Srnec. Zdroj: Archív autora.)
J. I.: Samozrejme. Nemôžem nespomenút' skladatel'a, ktorý zohral dost' vel'kú úlohu v mojom živote a v mojom ponímaní orchestra a prístupu k jednotlivým nástrojom. Bol to skladatel' z Moldavska, Pavol Borisovič Rivilis. Jeho cit pre orchestráciu a orchestrálny zápis boli absolútne excelentné. Niekol'ko rokov po sebe sme sa s ním pravidelne stretávali v Domove tvorby skladatelov v meste Ivanovo. Vždy to bolo vo februári. V Ivanove som sa tiež zoznámil s vynikajúcim človekom, skladatelom a muzikológom Borisom Gecelevym, s jeho manželkou Tamarou Levou, tiež muzikologičkou. S legendárnym moskovským pedagógom Jurijom Fortunatovym, s významnými muzikologičkami Innou Barsovou a Svetlanou Savenko a mnohými d’alšími. Večerné diskusie o hudbe, umení a živote boli pre mňa vzác-

ne a neuveritel'ne inšpirujúce. Domov skladatel'ov v Ivanove bol celkovo úžasné miesto, kde sa pravidelne stretávali mladí ludia zo všetkých republík bývalého Sovietskeho zväzu. Vždy to bola vel'mi pestrá paleta názorov, konfrontácia estetík, kompozičných techník. Večery sme trávili vzájomným počúvaním vlastnej hudby a museli sme neraz zniest' dost’ ostrú kritiku.

\section{P. J.: Ako vnímate otázku štýlu? Osobne vnímate svoj vlastný štylistický smer? Máte nejaké preferencie, uprednostňujete komponovanie v nejakom konkrétnom štýle?}

J. I.: Hned'ako som prišiel na Slovensko, cítil som, že vela l'udí chce moju tvorbu zaradit’ do nejakého štýlu, smeru, okruhu skladatelov. Niektorí sa ma otvorene pýtali, akú hudbu komponujem - atonálnu, dodekafonickú či v štýle Šostakoviča, minimal music atd'. Na jednom z koncertov istý muzikológ v úvodnom slove dlho rozprával o politickej situácii v predvojnovom a povojnovom Rusku, rozprával o koncentračných táboroch a zakončil to vetou „... a teraz tu máme skladatel'a z Ruska“. Politicky korektné publikum zatlieskalo, ale čo si pritom myslelo, zostalo pre mňa tajomstvom dodnes.

Snahy zaradit' umelca do nejakej skupiny, nejakého známeho smeru sú prirodzené a v podstate prítomné vo všetkých mne známych komunitách. Často počujem, ako niekoho zaradia do nejakého štýlu a vyslovia to ešte aj s určitým sarkazmom a povýšenecky, ako napríklad: „ale toto je taký minimalizmus“ alebo „toto je tonálna hudba“, 
a z toho tónu je cítit’ zrejmý podtext, že ide o jasnú vec a o tomto netreba vôbec ani diskutovat'.

V poslednej dobe evidujem snahu zaradit' ma medzi nasledovníkov Alfreda Schnittkeho. Určite sa dajú nájst’ v niektorých mojich skladbách spoločné črty s tvorbou Schnittkeho. Máme aspoň v niečom spoločný „background“. Leningradskí skladatelia boli nesporne pod vel'kým vplyvom osobnosti Šostakoviča nielen ako skladatel'a, ale aj ako človeka. Je to pochopitel'né, kedže Šostakovič učil dlhé roky v Leningrade. Učil však aj v Moskve a napríklad v prvých štyroch koncertoch pre husle a orchester od Alfreda Schnittkeho cítit’ silnú štylistickú nadväznost’ na tvorbu Šostakoviča. Hoci ja si osobne myslím, že je to skôr „intonáciou epochy“, ako písal Boris Asafiev a Dmitrij Šostakovič sa stal z vôle osudu najznámejším a najvýraznejším reprezentantom tejto doby, tejto intonácie. Napríklad, taký kolos ako Sergej Prokofiev, ktorý tiež mal svoj výrazný a špecifický rukopis, sa napriek nespornej genialite - tiež z vôle osudu - „intonáciou epochy" nestal. Schnittke bol o pät’ rokov starší ako Tiščenko, ale ako som už spomínal, Tiščenkova sláva bola v 60. rokoch vel'ká a Schnittke začal byt’ vel'mi uznávaný skôr až v druhej polovici 70. rokov. Samozrejme, že o sebe vedeli, komunikovali a vedome alebo podvedome absorbovali navzájom určité idey, či už hudobné, estetické alebo aj filozofické.

Dobre si pamätám, ako v roku 1986, ked’v rámci festivalu Leningradská jar odznela premiéra mojej kantáty pre zbor a cappella Epigrafy na básne Arsenija Tarkovského, jeden nadšený kolega, skladajúci väčšinou hudbu patriotickú a l'udovú, mi vrelo gratuloval: „To je skvelé, že si začal komponovat' hudbu v našom štýle!". A istý významný leningradský muzikológ, ktorý mal vždy po festivale oficiálnu záverečnú reč, v ktorej každého skladatel’a a každú skladbu dal do nejakého kvalitatívneho radu, na margo mojej skladby ironicky povedal: „No toto je priam Tanejev“.

Pojem podobnosti, kontinuity, určitého prevzatia v umení je proces prirodzený a vel'mi zaujímavý. Niekedy je vel'mi zaujímavé pozorovat', občas aj analyzovat', z ktorých zdrojov čerpá umelec vo svojej tvorbe. Ked'sa snažíme pochopit' tento proces v historickom priereze, nájdeme vel'a podobností nielen medzi skladatel'mi jednej epochy, jednej krajiny, ale niekedy aj medzi vzájomne vzdialenými tvorcami, časovo aj geograficky. Azda najvýraznejšie sa metóda „požičiavania“ či „prevzatia“ prejavila v systéme amerického pop-artu. Mám pocit, že výtvarníci sa zaoberajú týmto problémom ovela profesionálnejšie. Sú štúdie analyzujúce, napríklad, vplyv japonských motívov na anglické interiéry, alebo skúmajúce romantizmus vo Fínsku, alebo zaoberajúce sa problémom syntézy vo vytváraní štýlov kultúr latinskej Ameriky. V Rusku boli podobné diskusie vel'mi aktuálne. Záujem o „dialogické formy tvorby“ sa opieral o ideu vynikajúceho ruského filozofa, teoretika kultúry Michaila Bachtina. Žial', muzikológia sa tejto problematike venuje ovel'a menej, a to aj napriek tomu, že polyštýlovost', polyštylistika ako spôsob organizácie zvukového priestoru vždy bola vo väčšej alebo menšej miere prítomná v tvorivom procese. Dnes polyštylistiku absolútne vedome a pomerne často využívajú rôzni autori. Nakoniec, jeden z nesporne najväčších skladatel'ov všetkých čas, J. S. Bach, bol tiež vo svojej tvorbe v určitom zmysle slova polyštylista, kedže dokázal objat' a zosumarizovat’ celú predchádzajúcu epochu.

Paradoxne však niektoré skladby mladého Mozarta si možno pol’ahky zamenit’ a pripísat’ ich Beethovenovi a naopak. Rachmaninov dost’ dlho trpel kvôli tomu, že niektorí považovali jeho hudbu za napodobeninu Čajkovského, atd'. Ja si osobne myslím, že 
v prvom rade predsa rozhoduje kvalita konkrétnej skladby, a nie jej štylistická podobnost'. A samozrejme, treba dodat', že všetko je dost' relatívne.

\section{P. J.: Čo si myslíte o postavení klasickej hudby v súčasnej dobe? Ako jej postavenie vnímate?}

J. I.: Každá epocha má svoju vlastnú spiritualitu, odlišnú od iných časov. Vasilij Kandinskij napísal začiatkom 20. storočia geniálnu - ešte stále aktuálnu - knihu O duchovnosti v umení. Táto duchovnost’ je zachovaná umením každej éry - renesancie, baroka, romantizmu atd'. Najväčšie diela prežívajú svoj čas a zostávajú pre budúce generácie. Zdá sa, že čas má dočasnú spiritualitu, duchovnost', ktorá s ňou zomiera, a vyššiu, ktorá zostáva vyjadrená v umení. Približne tak sme si (alebo možno len ja?) doteraz vysoko cenili, napríklad, hudbu Beethovena, pokladajúc ju za nesmrtel'nú. Avšak dvaja autori, muzikológ Nat Sloan a skladatel' piesní Charlie Harding, obvinili hudbu Beethovena z toho, že patrí k utláčajúcej elitnej klasickej kultúre, podporujúcej nadvládu mužov, potláčajúcej hlasy žien, černochov a LGBTQ komunity.

„Časy si nevyberáme, v nich žijeme a zomierame," tak písal významný ruský básnik Alexander Kušner. $V$ dnešnej dobe musíte jednoducho dávat' vel'ký pozor, čo hovoríte a v akom kontexte. Viac ako v minulosti platí výrok, že „každé slovo môže byt’ použité proti vám". Stačí len spomenút na čerstvý príklad J. K. Rowlingovej. Ja by som tu dodal, že aj „,každá nota môže byt' použitá proti vám”.

\section{P. J.: Ste široko mysliacim umelcom, ktorý tvorí nielen hudbu. Ste i hudobným inter- pretom, výtvarníkom, literátom, dlhé roky sa venujete šachu... Čo vaše inšpirácie?}

J. I.: Trochu provokatívna otázka. Totiž je dost’ otázne, či som naozaj až tak „široko mysliaci umelec". Prvá asociácia je, samozrejme, spomienka na metaforu od Blaise Pascala - človek je "mysliaca trstina”. Vždy d’akujem svojmu osudu, že som mal to štastie poznat' naozaj široko mysliacich, vel'kých l'udí neuveritel'nej erudície a rozhl'adu. Niektorí boli slávni, niektorí nie, niektorých som poznal viac, niektorých som stretol letmo, ale vždy to vo mne zanechalo úžasný pocit. $V$ prvom rade musím spomenút svojho otca. Bol nielen výborným huslistom, ale aj neuveritel'ne vzdelaným, erudovaným a talentovaným človekom. Mal úžasný cit na písanie textov a básní. Bol schopný napísat’ básničku behom piatich minút. Párkrát som sa ho pýtal, prečo vlastne nepíše ako naozajstný spisovatel'. Vždy mi odpovedal otázkou - „A na čo?”. Často, ked' začínam niečo komponovat', kladiem si tiež túto otázku.

Práve vd'aka otcovi som sa priučil pozerat' na nejaký problém alebo vec z rôznych uhlov. Myslím si, že aj šachy, ktorým som venoval dost' času, nútili ma byt' opatrným a zvažovat’ následky d’alšieho t’ahu. Nielen hrubo či mechanicky počítat’ varianty, ale rozmýšlat’ z pohladu stratégií, taktiky a v určitom zmysle aj psychológie a filozofie. Ak by som sa snažil odpovedat' na vašu otázku dôslednejšie, vyzeralo by to, že píšem pamäti a potreboval by som na to možno aj pár rokov. Neviem, či by tie pamäti boli pre niekoho zaujímavé a či by boli prínosom pre údajne budúce generácie. Inšpirácie majú vel'mi rôznorodý charakter.

Dovolím si tvrdit', že niečo sa dá vidiet’ aj v názvoch mojich diel a sú aj také, o ktorých neviem ani ja sám. 
Osobne si myslím, že skladatel'a, ako aj každého iného človeka, ovplyvňuje nielen hudba, ale tiež vela rôznych vecí: literatúra, poézia, výtvarné umenie, film, história, príroda... Je to vlastne syntéza všetkého, čo vás obklopuje, vrátane reálneho, každodenného života. Občas sa naozaj cítim, akoby som bol tým ohnivkom v ret’azi, o ktorom písal Roland Barthes v eseji Smrt'autora.

\section{P. J.: Čo pre vás znamená tvorba? Priblížili by ste akt vášho komponovania?}

J. I.: Už asi niekol'kokrát som v rozhovoroch alebo článkoch hovoril, že pre mňa je tvorba formou určitého dialógu. Dialógu s minulostou, súčasnostou alebo s konkrétnym autorom, epochou či štýlom. Často používam spôsob skrytého citovania. V každom prípade sa snažím vždy udržat', aspoň z môjho uhla pohladu, najvyššiu úroveň remesla, zručnosti, najvyššiu kvalitatívnu úroveň vo svojich skladbách, v tom štýle, v akom momentálne pracujem. V jednej úžasnej čínskej príručke pre maliarov som našiel nasledovnú definíciu takejto zručnosti: „Zručnost', kde nie je viditel'ná žiadna zručnost'. Konečným cielom je zvládnut metódu tak, aby sa zdalo, že neexistuje." Ked' komponujem nové dielo, vždy túžim skomponovat’ skladbu, ktorá by pôsobila ako práve teraz stvorená živá a prirodzená improvizácia.

Ak by som mal sily a čas, možno by som sa podujal na výskum, prečo nejaký obraz, nejaká skladba, dielo pôsobí na človeka vel'mi silne a iný obraz, skladba, dielo zasa nie. Je v tom špeciálny sklon línií, timbrov jednotlivých nástrojov, tajomstvo využitia špeciálnych kombinácií farieb? Alebo možno publikum je ovplyvnené verejnou mienkou, ktorá uznala niečo za majstrovské dielo?

Dávnejšie som napísal esej o čase a kontrastoch. Mal som pocit, že to je najdôležitejšia substancia hudobného priestoru. Ked' si však pomyslím, že napríklad v inej galaxii čas beží úplne ináč, uvedomujem si, že naše predstavy a pocity platia len tu, medzi nami, na Zemi.

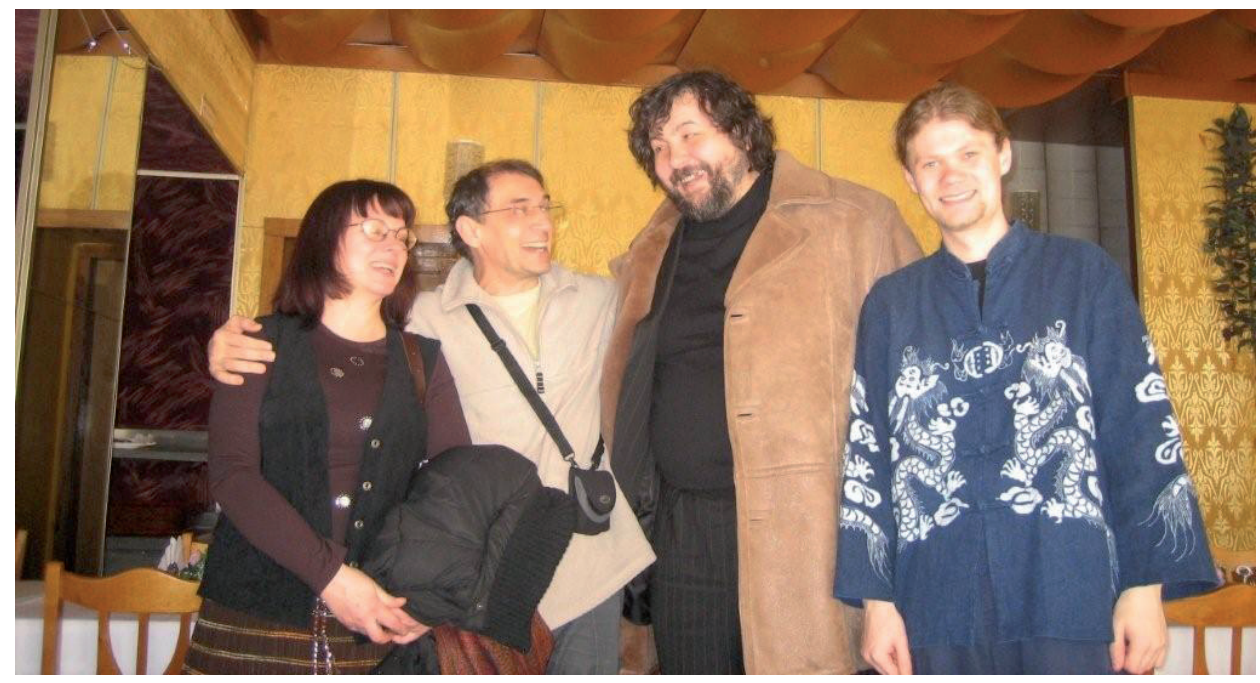

Obr. 2: Zl’ava: Anna Sčerbaková, Jevgenij Iršai, Igor Ščerbakov, Milan Pala. (Zdroj: Archív autora.) 
Neviem vysvetlit', ako komponujem. Ak idem niečo komponovat', či už len tak pre vnútornú potrebu alebo občas na nejakú objednávku, nikdy dopredu nemám jasnú predstavu o forme alebo iných detailoch skladby. V prvom rade hladám materiál, ktorý sa mi zdá byt' vhodný. Následne sa snažím čo najprecíznejšie do neho vžit’ a pochopit', čo je preň najprirodzenejšie, akou technikou s ním mám narábat', aby som ho nepoškodil.

Najlepší čas na komponovanie alebo písanie textov pre mňa nastáva medzi druhou a tretou v noci. Zobudím sa, rozmýšl'am, fantazírujem... Práve vtedy prichádzajú úžasné ( v polospánku sa všetko zdá úžasné), originálne myšlienky. Ked’ som bol mladší, dokázal som vstat’ a ihned' myšlienku zapísat'. V Banskej Bystrici, kde som býval do roku 2008, som mal pri posteli elektrický klavír Clavinovu. Ten mal nahrávací pás. A tak som potme zapol nahrávanie, nahral to a spal d’alej. Ráno som to mal. Čestne priznávam, že väčšinou to bolo o ničom, ale občas predsa zaujímavé. Teraz som lenivý. Spolieham sa, že do rána to nezabudnem. Ale kdeže! Samozrejme sa trápim, ale skoro nič si nepamätám. A možno je to aj dobre. Možnože úplne stačí, že v noci mám dobrý pocit, že tvorím.

\section{P. J.: Ako si spomínate na svojich pedagógov?}

J. I.: Prvým mojím učitel’om kompozície ešte na strednej škole bol Sergej Jakovlevič Vol'fenzon. Bol to človek vysokej inteligencie. Vynikajúco hovoril francúzsky. Vychoval desiatky významných skladatelov. Z tých, čo som už spomínal, to bol napríklad Sergej Slonimskij, Valerij Gavrilin, Andrej Petrov, Genadij Banščikov a mnoho d’alších.

Dbal na dôslednú prácu s hudobným materiálom a učil tvorbu melodickej línie. Napísat' melódiu, aby bola pútavá a zároveň aspoň trochu originálna, je vel'ké umenie. Občas si myslím, že je to nejaký dar a t’ažko sa tomu umeniu dá naučit', ale oplatí sa snažit'.

Študoval som aj v odbore hra na klavíri. Na strednej škole som chodil do triedy vynikajúceho pedagóga - Tatiany Borisovny Rumševič. Vlastne prijímačky na Konzervatórium som robil z hry na klavíri. Na štúdium kompozície som mohol nastúpit’ až po prvom polroku v prípade, ak by som mal výborné známky zo zimných skúšok. Tak som sa snažil. Na Konzervatóriu sa mojím učitelom klavírnej hry stal Pavel Alexejevič Serebrjakov. Všetci moji pedagógovia hry na klavíri dávali velký pozor na kvalitu zvuku, kvalitu dotyku s klávesmi. Spomínam si na jedného vynikajúceho nadaného klaviristu Dmitrija Moločnikova. Hovorili o ňom, že je génius. Mal - bohužial' - schizofréniu, ktorá sa začala uňho prejavovat’ vo veku 20 rokov. Takmer celý svoj život strávil v nemocniciach. Ked'mal však občas zlepšenie stavu a bol vonku, často chodil k nám na návštevu.

Raz ma požiadal, aby som mu zahral Chopinovo Nokturno cis mol, ktoré som vtedy cvičil. Následne si sadol za ten istý, už dost' starý klavír a ten pod jeho neuveritel'ne dlhými prstami začal spievat', akoby to bol ludský hlas. Vtedy som pochopil, čo je naozajstné legato, čo je naozajstný dotyk a snažil sa som ho potom vždy napodobnit' a dosiahnut’ krásny tón na akomkolvek nástroji.

\section{P. J.: Z akého rodinného zázemia pochádzate? Išlo o profesionálne hudobnícke prostredie?}

J. I.: Narodil som sa v rodine profesionálnych hudobníkov. Mama bola klaviristka a otec huslista. Do mojich piatich rokov sme žili s rodičmi a bratom v jednej, asi 20 met- 
rov vel'kej izbe, ktorú delila na dve časti vysoká skriňa. Pred skriňou bola obývačka a za ňou priestor na spanie. K otcovi občas chodilo zopár žiakov na súkromné hodiny. Okrem našej rodiny v byte bývali ešte štyri d’alšie rodiny. Ked' som mal pät’ a pol roka, prest’ahovali sme sa do iného bytu. Okrem nás tam bývala ešte jedna rodina a mali sme už dve spojené izby. Jedna bola velikánska, asi 35 - 40 metrov štvorcových. Druhá okolo 12 metrov štvorcových. Vo vel'kej izbe rodičia hned' postavili maličký klavír značky Mühlbach a v malej pianíno Krásnyj Oktabr (Červený október). V Rusku to bola významná firma, ktorá sa zaoberala výrobou hudobných nástrojov. Neskôr sa otcovi po dohode podarilo z týchto dvoch izieb urobit' samostatný byt. Takmer každý deň sme mali hostí. Väčšinou to boli hudobníci, kamaráti rodičov, ale chodili k nám aj ludia iných profesií. Často som býval svedkom vášnivých diskusií o literatúre, vesmíre, klimatických zmenách, mimozemštanoch atd'. Ak by som skúsil porovnat tú dobu a tú súčasnú, v prvom rade by som zdôraznil, že vtedy sa naozaj diskutovalo. Áno, občas to samozrejme zaiskrilo, ale vždy to bolo korektné. Vždy vás pozorne vypočuli a argumentovali, nikdy neosočovali len tak. Teraz, bohužial', zvlášt' na takzvaných sociálnych sietach, ak máte iný názor, takmer vás nevypočujú a okamžite zapíšu medzi nepriatelov. Väčšinou chodili k nám muzikanti a doma sa začalo muzicírovanie. Boli to výborní a vel'mi uznávaní muzikanti nielen v Peterburgu (teda v Leningrade) - profesori konzervatória Jevgenij Šenderovič, Jurij Kramarov, Boris Rafal'son, Felicia Fondamiskaja, Anatolij Badchen a vel'a vela iných.

Rád by som tu spomenul otca sesternice mojej mamy, Natálie. Ešte na vysokej škole sa vydala za Slováka a emigrovala s ním do Banskej Bystrice. Vlastne na jej pozvanie som aj ja prišiel v roku 1991 na Slovensko. Jej otec a môj ujo Konštantín Terechov pôsobil ako inžinier pre vel'kú spoločnost'. Za mlada boxoval a bojoval na majstrovstvách Leningradu. Bol to vel'ký, silný muž. Nikdy neštudoval hru na klavíri, ale mal zázračnú schopnost' okamžite si zapamätat' raz vypočutú hudbu a hned' ju zahrat' svojimi vel'kými a tarbavými rukami na pianíne alebo klavíri. Takú unikátnu pamät mal Rachmaninov. Robil aj triky. Napríklad klaviatúru zakryli kúskom látky a potom hral naslepo, ale presne. Bol som nadšený, ale tiež som mu závidel túto jeho schopnost' - prečo ja nemám takú úžasnú pamät'? Mal som ho vel’mi rád. Vd’aka nemu som mal možnost' poznat' úplne iný svet, iných ludí. Napríklad, stretol som u neho brata legendárneho ruského akademika Dmitria Lichačova, Michaila. V určitom zmysle, nevediac a určite aj nechtiac, môj ujo prispel k tomu, že som nezasvätil svoj život výlučne hre na klavíri. V híbke duše som si myslel, že ak chcem byt' koncertujúcim klaviristom, musím mat’ pamät’ ako Konštantín.

\section{P. J.: Napriek tomu ste činorodý aj ako klavirista, nahrali ste diela Bacha, Mozarta, Beethovena, Chopina i mnoho vlastných skladieb. Študovali ste i hru na klavíri. Ako sa vyvíjala v Rusku vaša činnost' či kariéra klaviristu? Ako sa vyvíjala v Rusku vaša kariéra skladatela?}

J. I.: Odpoved'na túto otázku možno prekvapí, ale musím úprimne povedat', že som nikdy nevnímal svoju činnost’ ako kariéru. Bol to môj život a nejako som nerozmýšlal nad tým, či robím nejakú kariéru. Prijímal som všetko, čo prichádzalo do môjho života a snažil som sa prijímat' to s pokorou - napriek výchove v ateizme. Bohužial', bol som dost' lenivý a mal som vel'a iných záujmov, a preto som aj nie vel'mi pravidelne cvičil. Prednedávnom som v jednom rozhovore spomínal, že som úplne vážne uvažoval byt’ 
aj spisovatel'om, lekárom, hercom, režisérom či profesionálnym šachistom. Zostal som nakoniec pri hudbe. Samozrejme vždy, ked'som musel hrat' nejaký repertoár alebo aj vlastné skladby, chcel som hrat' čo najlepšie, preto som cvičil. Takisto, ked' som komponoval alebo aj teraz občas komponujem, chcel som a stále chcem komponovat' čo najlepšie. Lenže tie predstavy o tom, čo je najlepšie, sú dost' subjektívne. Čas beží, dozvedáme sa nové informácie, prichádzajú nové technológie, menia sa naše predstavy o dejinách, menia sa názory, estetické ideály, formy a normy komunikácie. Každý má iné kritériá. Iné ciele, iné vzory. Skrátka, každý má svoju pravdu.

Treba brat’ do úvahy aj neuveritel'né zrýchlenie nášho života. Svetoznámy ruský vedec Sergej Kapica v jednom zo svojich posledných interview poznamenal, že „historická epocha", ktorá kedysi trvala niekol'ko stáročí, sa dnes skrátila do života jednej generácie. Dnešní mladí ludia často nevnímajú veci, ktoré pre moju generáciu boli absolútne prirodzené. Dnes často počúvam stažnosti na prerušenie spojenia generácií, na umieranie tradícií - ale možno je to prirodzený dôsledok zrýchlenia histórie. Každá nová generácia žije vo svojej dobe. Mám pocit, že toto zrýchlenie sa už nikdy nezastaví. A nie je to vôbec kritika. Nové formy umenia, nové estetické ponímanie umení, ktoré prináša a občas aj diktuje nová generácia, môžu prekonat’ duchovný vývoj nielen diváka, ale aj profesionálov staršej generácie a, samozrejme, schopnost’ vnímat' meniaci sa svet. Jednoducho, človek patrí do svojej doby.

P. J.: Ako na svoju tvorbu hl'adíte spätne, z dnešného uhla pohladu? Máte vo svojom diele oratóriá, kantáty, Rekviem, symfonické diela, koncerty, duchovnú zborovú tvorbu, pät' sláčikových kvartet, sedem klavírnych sonát, tri sonáty pre husle a klavír, množstvo komornej hudby, piesňové cykly... Máte vo vašej tvorbe skladbu či obdobie, ktoré vám je najbližšie?

J. I.: Toto je otázka, na ktorú by sa dalo odpovedat' niekol'ko dní. Všetky obdobia môjho života sú pre mňa vzácne. Na každé obdobie mám nostalgické spomienky a občas mám pocit, že by som rád niektoré prežil ešte raz, alebo niektoré aj dvakrát. Iná vec je skúsit’ ich hodnotit’ z pohl'adu nejakého dôležitého rozhodnutia. Viete - ako u O. Henriho v poviedke Cesty, ktoré si vyberáme.

V tomto prípade by som tu spomenul epizódu, ktorá sa stala, ked’ som bol v druhom ročníku vysokej školy. Tesne pred skúškami, približne dva mesiace predtým, zomrel na rakovinu môj oblúbený profesor Černov-Pen, ktorého som poznal ešte z detských čas. Bol som dost' rozrušený a skomponoval som cyklus piatich piesní na básne Alexandra Bloka. Môj prvý učitel' kompozície, Volfenzon, ktorému som tento cyklus ukázal, bol nadšený. Následne som tie piesne prezentoval na našom pravidelnom stretnutí študentov skladby v rámci kompozičného klubu. Tam som zažil tiež vel’a chvály. Avšak na skúške to dopadlo katastrofálne. Dostal som hodnotenie 2, čo na Slovensku je v podstate 5, v indexe som mal napísané „profesionálna neschopnost" a dali mi polroka na opravu. Emocionálne a psychicky to bol pre mňa vel'ký šok. Študoval som paralelne aj klavír a na skúškach som mal jednotku (v Rusku 5), ale už som cítil, že klavír ma až tak nebaví. Začal som intenzívne uvažovat', či mám pokračovat’ v štúdiu, alebo sa na to vykašl'at’ a íst' na prijímačky na herectvo. Vtedy som už presne vedel, že ani medicína ma až tak nebaví. Volfenzon s tým však nevel'mi súhlasil a začal zistovat', prečo som dostal také hodnotenie a volal vtedajšiemu vedúcemu katedry, Orestovi Jevlachovovi. 
Neviem, či to bola pravda, alebo ma Sergej Jakovlevič Volfenzon chcel jednoducho mentálne podporit', ale vraj Jevlachov povedal, že skladba nebola až taká zlá, ale komsomolec nemôže písat piesne na básne plné pesimizmu a takých slov ako „trúchlivý“, ,,smrt', ,",hrobka“ atd'. Túto epizódu, nesporne rozhodujúcu pre môj život, možno posudzovat' z rôznych hl'adísk a rôzne interpretovat'. Prečo sa to stalo tak a prečo som sa zachoval, ako som sa zachoval, pretože napokon som zostal pri hudbe, a napriek tomu, že toto rozhodnutie nelutujem, doteraz neviem, či to bolo správne rozhodnutie. Súvisí s tým ešte jedna, pre mňa vzácna epizóda, a to reakcia Sergeja Slonimského, ktorého som si nesmierne vážil a vážim si doteraz. Bol to vel'ký skladatel' a vel'ký človek. Slonimskij ma velmi skritizoval za ten cyklus. Velmi ma to mrzelo a možno práve aj kvôli tomu sme mali roky vel'mi chladný vztah. O to vzácnejšia bola Slonimského pochvala mojej zborovej kantáty Epigrafy. Bol som mimoriadne štastný, ked'ku mne Slonimskij po premiére pristúpil a povedal: „Toto je majstrovské dielo“. Od tej chvíle sme mali vždy výborný vzt’ah. Pamätám si, ako v Peterburgu zaznela v podaní Milana Pal'u premiéra Sonáty Nenávist’ a Sergej Michajlovič zase vychválil moju hudbu a, samozrejme, aj Milanovu interpretáciu. Táto skladba, žial', nie je na pódiách vel'mi žiadaná. Ked’sme ju napríklad chceli hrat' v Ostrave, povedali nám, že hudba s takým názvom zniet’ nemôže. Márne som sa snažil presvedčit' a vysvetlit', že ide o nenávist’ v spoločnosti, ktorú ostro pocitujem a že ja osobne som práve proti nenávisti, a preto som túto skladbu tak aj nazval. Nič nepomohlo. Skomponoval som tú Sonátu asi v roku 2004 a mám smutný pocit, že tej nenávisti, neznášanlivosti v našej spoločnosti odvtedy len pribudlo.

Čo sa týka d’alších skladieb, je to trochu lahšie. Mal som niekol'ko väčších ideí a podarilo sa mi ich realizovat'. V prvom rade je to Rekviem, potom Schoenberg Variations, Slovenský zošit na básne Ivana Kraska, Šest' Bratislavských koncertov, Proglas, Stabat Mater, Sun Symphony of Wind Instruments, A Glass of Glass atd.'

\section{P. J.: Už niekol'ko desiatok rokov ste vyhladávaným pedagógom. Čo by ste povedali o svojej pedagogickej praxi?}

J. I.: Zhodou okolností som pred pár týždňami odpovedal na podobnú otázku. Nerád sa opakujem, ale v tomto prípade niečo z tej odpovede predsa zopakujem. Učit’ som začal ešte počas štúdia na vysokej škole. Teda na Konzervatóriu v Leningrade. Vždy som rád učil. Núti to hlbšie pochopit’ problém, aby ste ho mohli vysvetlit’ študentovi. Preto odporúčam každému môjmu študentovi, aby aspoň nejaký čas učil, hoci aj na základnej umeleckej škole. Nakoniec je to unikátna možnost’ stretávat’ sa a diskutovat’ s mladými l'ud'mi. Vždy som sa snažil dat' každému adeptovi vieru v jeho sily. Inšpirovat', podporit’ tvorivý proces. Najviac som sa tešil a stále sa teším z tých študentov, ktorí na prvý pohlad nie sú vôbec vel'mi nadaní, ale napokon sa vypracujú na vel'mi slušnú úroveň a nájdu seba a svoje miesto v živote. Bol som ešte dost’ neskúsený v pedagogike, ked' za mnou prišiel otec jednej dievčiny, ktorá bola, ako sa hovorí, „na vyhodenie“. Prosil ma, aby som ju zobral do svojej triedy, pretože si evidentne nerozumela s učitelom. Mala problémy so všetkým, dokonca aj so zápisom nôt. Bolo mi jej lúto, a tak sme sa korektne dohodli s jej pedagógom a začal som sa s ňou rozprávat’ a diskutovat’ o všeličom. A tak sa postupne niečo začalo menit’ k lepšiemu. Teraz komponuje skvelú hudbu, vydala niekol'ko vel'mi zaujímavých kníh o súčasnej hudbe a je v Rusku vel'mi uznávaná a oblúbená u študentov. Mal som však štastie aj na vel'mi nadaných študentov, aj na 


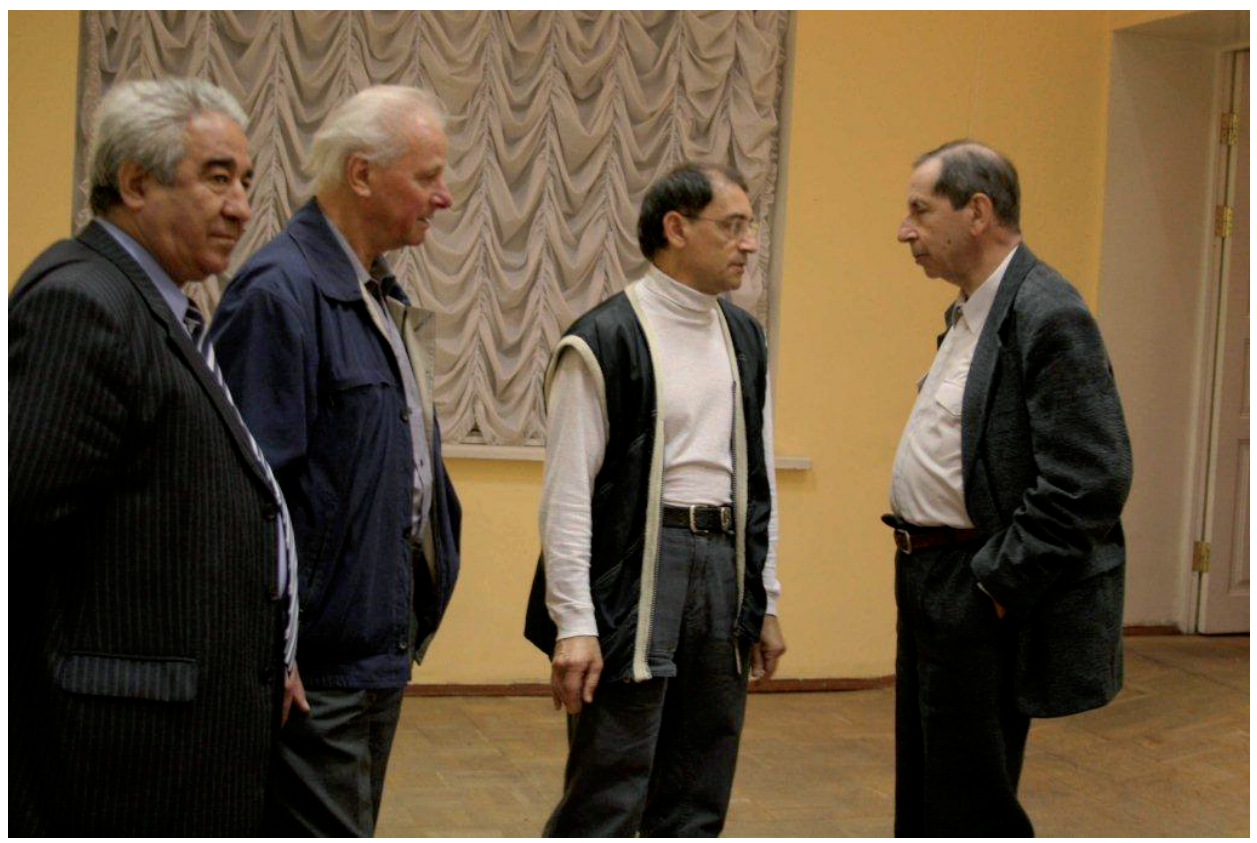

Obr. 3: Druhý zl'ava: Vladislav Černušenko, Jevgenij Iršai, Sergej Slonimskij. (Zdroj: Archív autora.)

študentov, s ktorými som, takpovediac, od prvej chvíle cítil príbuznost’ v pohladoch nielen na hudbu, ale aj na život.

\section{P. J.: Možno banálna otázka, avšak vaša odpoved' zaiste banálna nebude: Čo zna- mená sedemdesiatka?}

J. I.: V prvom rade je to číslo. Vždy ma zaujímalo, prečo vlastne každá spoločnost’ tradične pridáva taký symbolický význam takzvaným okrúhlym dátam. Štyridsiatka, pät'desiatka, šest'desiatka atd'. Na jednej strane je pochopitel'né, že existujeme v desiatkovej sústave a je to najjednoduchší spôsob delenia časových úsekov. Na inej planéte, kde beží čas úplne inak a možno by používali iný matematický model, určite by boli iné spôsoby merania. Na druhej strane možno vidiet', napríklad aj na životopisoch významných ludí, že zmeny v ich živote prichádzajú nesúvisiac s touto tradíciou. Možno vás rozčarujem, ale nemám pocit, že práve teraz viem odpovede na otázky, ktoré si kladiem takmer celý svoj život. Mám viac skúseností? Asi áno. Mám, ako sa hovorí, viac rozumu? Neviem. Stal som tolerantnejším? Nemyslím si. Možno viac viem, vidím viac do híbky? Toto je vel'mi relatívne. Áno, ovela viac viem o období spred 50 rokov. Preto samozrejme hodnotím súčasné udalosti okolo nás ináč ako mladí ludia, ktorí nezažili a nevedia nič o tom, ako sa žilo v 60. - 70. rokoch minulého storočia. Či je to však nejaká výhoda? Občas mám len pocit, že mám preplnené bunky pamäti. Skrátka neviem. Rozhodne neviem tak rýchlo behat’ ako za mlada, a to ma mrzí. Už nedám celé futbalové ihrisko dvakrát po sebe v maximálnej rýchlosti. 
Jeden z najväčších básnikov 20. storočia pôvodom z Ruska Josif Brodskij v jednom svojom verejnom prejave vel'mi stručne a presne sformuloval dost' dôležitú podstatu nášho bytia. Vyjadril to vel'mi metaforicky. Povedal doslova: ....my sme, žijeme v demokracii - $v$ tomto domove na polceste medzi nočnou morou a utópiou.... Ked' hodnotím (a ako ináč, predsa nič ludské nie je pre mňa cudzie) svoj život, musím uznat', že som mal obrovské štastie a môj život bol ovel'a bližšie k utópii. Cítim preto vel'kú úctu a zodpovednost pred tými, ktorí boli na opačnom konci bližšie k „nočnej more“. Verím, že ešte nejaký čas na tejto zemi mám a vel'mi dúfam, že sa podarí realizovat' ešte niečo dobré. Či to bude v hudbe či v medziludských vztahoch - neviem. Len dúfam.

\section{P. J.: Aké sú vaše najbližšie plány?}

J. I.: Naučit' svoje deti hovorit po rusky. Taktiež by som sa chcel naučit hrat' na niektorých hudobných nástrojoch, malú zbierku ktorých vlastním. Rozmýšlat', čítat', mal'ovat', prechádzat' sa - jednoducho jedným slovom - žit. 